Jpn. J. Pharm. Health Care Sci.
ノート 34(6) 586-592(2008)

\title{
がん薬物療法における薬㓢師による処方鑑査の有用性
}

岡澤美貴子 ${ }^{*}$, 鈴木麻由香, 本田麻子, 坂田修一, 折井孝男

NTT 東日本関東病院薬剂部

\section{Usefulness of Prescription Checking by Pharmacists in Cancer Chemotherapy}

\author{
Mikiko Okazawa*, Mayuka Suzuki, Asako Honda \\ Syuuichi Sakata and Takao Orii \\ Kanto Medical Center NTT EC Pharmacy Department
}

$\left[\begin{array}{l}\text { Received A ugust 3, } 2007 \\ \text { Accepted March 7, } 2008\end{array}\right]$

In cancer chemotherapy, it is essential for pharmacists to fully understand dosing regimens and precautions in the use of anticancer agents to ensure rational prescribing.

At the Kanto Medical Center NTT EC, pharmacists are involved in regimen management to ensure effective and safe chemotherapy from the pharmaceutical perspective. In this study, we investigated the usefulness of prescription checking by pharmacists in ensuring rational prescribing.

The number of prescriptions for anticancer agents checked by pharmacists during the six months from October 2006 to March 2007 was 1,275 and the total time taken for checking prescriptions, including the confirmation of questionable points and prescription corrections, was 83 hours and 35 minutes. The average time taken per prescription was 3.5 minutes. On each day, prescription checks were conducted by 1 or 2 pharmacists. Of 105 prescriptions, 11(10.5\%) were corrected by pharmacists, with the corrections concerning inappropriate doses, essential medicines that were missing from prescriptions and duplication of medicines. Such errors occurred despite regular regimen management.

Our findings show that prescription checking by pharmacists is useful in ensuring that prescribing is rational and achieves effective, safe chemotherapy. The results of this study also showed that pharmacists need to carry out prescription checking based on an understanding of physicians' intentions, an adequate knowledge of the drugs concerned and familiarity with the electronic medical records system.

Key words — cancer, chemotherapy, prescription checking, risk management

\begin{abstract}
緒言
近年，がん薬物療法は著しく進歩している.1990年 代以降, 国内の臨床試験における基準がICH-GCP(International Conference on Harmonization of Technical Requirements for Registration of Pharmaceuticals for Human UseGood Clinical Practice ; 医薬品規制調和国際会議 - 医薬 品の臨床試験の実施に関する基準)により国際的に向上 が図られた .これによって，急速に新しい抗がん斉の開 発が進められた . 支持療法も可能となり，がん薬物療法 が一段と進んだ”．厚生省(現厚生労働省)は1998年より 関係学会と医薬品等の適正使用を推進し，公的事業のな
\end{abstract}

かで, 抗がん剂適正使用ガイドライン作成の検討を日本 癌治療学会と日本臨床腫瘍研究会に委託し, 2002年に 「抗がん斉適正使用のガイドライン」が公表された . ま た，個別専門学会では当該疾患に対するガイドラインの 作成が精力的に行われ, 食道がん, 胃がん, 大腸がん， 肝がん, 脺がん, 肺がん, 乳がん, 子宮体がん, 卵巣が ん, 前立腺がん, 皮膚悪性腫瘍のガイドラインが公表さ れ, がん診療における情報の均霑化が進められている． また，現在のがん薬物療法では単剂で投与されること は少なく多剂併用が主流となっている．つまり，同一薬 剂の組み合わせであっても，標的藏器ごとに投与量や投 与スケジュールが異なる．また，使用される抗がん剂の 剂形の多くは注射薬であり，細胞毒性が強く使用方法を 
誤ると患者の健康に重篤な影響を及ぼす可能性がある゙2.

このような進歩が著しく複雑ながん薬物療法を，有効 かつ安全に患者へ提供するためには, 薬阂の特性につい て十分な知識を持つ薬剂師が，レジメン作成の段階から 関与する必要がある .

薬剂師によるレジメン管理や処方鑑査は，抗がん阁を 処方する医師からもきわめて重要な業務として認識され ている ${ }^{3} \cdot$ 薬剂師は薬学的見地からのみでなく，運用面 においても医師や他のスタッフの過誤を防ぐことも考慮 し，レジメン管理と処方鑑査を行う必要がある。

NTT 東日本関東病院(以下，当院と略す)では 2000 年 12月より電子カルテによるレジメン管理が行われてい る. 兴の際, 薬剂師がレジメンの薬斉の種類, 投与量, 投与経路，投与時間，投与開始時間，投与間隔が適切に 設定されているか確認を行い, 有効かつ安全に化学療法 が行われるようレジメン作成にかかわっている．ただ し，レジメンは標準的な処方の設定となるため，患者の 状態にあわせたレジメンに一部調整する必要が生じる． 弚のため, 当院では必要に応じて医師がレジメンを調整 できるシステムとしている。しかし，医師が調整時に 誤った操作をするリスクは，レジメン管理だけでは防止 できない .

このようなことから，本研究では，調製前処方鑑査に よる処方の適正化の有用性について検討した .

\section{方法}

調査期間は 2006 年 10 月から 2007 年 3 月までの 6 力 月間とした . 調査対象は調査期間中に入院し抗がん阂治 療を受けた患者 377 名，男性 245 名 $65 \%$ ），女性 132 名 (35\%)とした . 調査内容は，平日 15 時から 17 時に調製 前処方鑑査薬剂師が鑑査した抗がん斉処方せん枚数，処 方鑑査に要した時間，疑義照会した内容とした .なお， 当院におけるレジメン管理体制，医師が処方設計時に行 うレジメンの調整，薬斉師の処方鑑査体制と調製前処方 鑑査薬阂師による処方鑑査方法を以下に記載した。

\section{1. 当院におけるレジメン管理}

当院では, 電子カルテにレジメンとして登録されてい なければ抗がん阂を処方することはできないシステムと し，手書き処方による抗がん斉の投与を認めないことと した、レジメン登録のながれを示した(図1). 新規レジ メン登録を希望する医師(以下, 申請医師と略す)が，レ ジメン登録申請用紙(以下，申請用紙と略す)に必要事項 を記入し，薬斉部に提出するながれとした . 申請用紙の 記載内容は薬剂名，投与量，投与量の上限値，点滴時間 と速度，抗がん剂を溶解する輸液の薬剂名や投与量，投 与間隔とした．制吐剂，アレルギーを予防する薬阂など

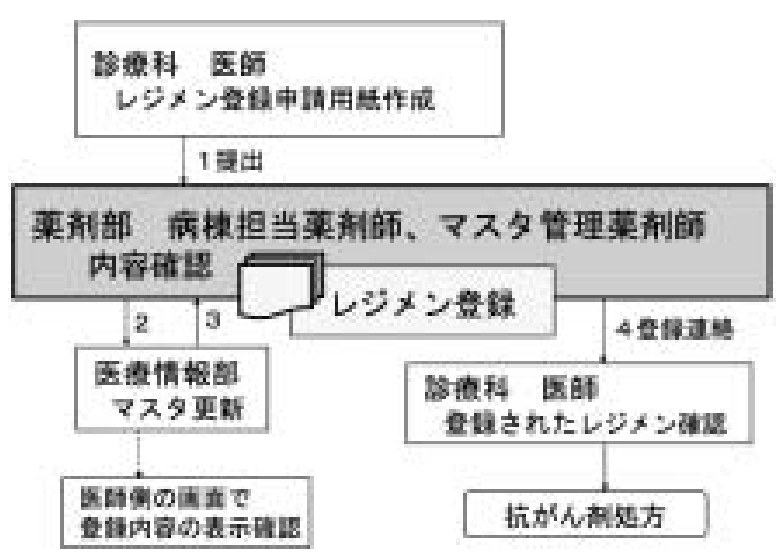

図 1.レジメン登録のながれ

当院でのレジメン登録のながれについて示した . 当院では 登録されていないレジメンを用いてがん薬物療法を行うこ とはできない．医師より提出されたレジメン登録申請用紙 を薬剂師が確認し, 問題点がある場合は解決してからレジ メン登録を行う.レジメン登録終了後, 医師は処方画面で 正しく処方できるかどうか確認する.

抗がん斉以外の併用薬についても記入することとした . また，診療科部長の了承および押印のない申請用紙は薬 剂部で受け付けない規則とした。さらに，個人的な研究 目的等ではレジメンが登録できないシステムとした 。

薬斉部に提出された申請用紙の記載内容を，病棟担当 薬斉師とマスタ管理担当薬斉師が確認した．まず，レジ メンの対象となる患者や治療のなかでのレジメンの位置 づけ，エビデンスがあることを確認した .

薬斉部では，改善が必要なレジメンがあれば申請医師 や他のスタッフと相談し, 問題を解決した後, マスタ管 理担当薬剂師がマスタ登録することとした . 兴の後，医 療情報担当者がマスタの更新を行い，医師の処方設計画 面の確認を行った．医療情報担当者は一連の作業終了 後, 光の旨を薬阂部に連絡し, 薬斉部より申請医師にレ ジメン登録終了の連絡を行った，連絡を受けた申請医師 は処方画面で登録内容に不備がないことを確認した。

また，レジメンは診療科別に登録し，他科のレジメン を用いて処方することはできない規則とした . 医師の処 方設計画面には所属する診療科のレジメンだけが表示さ れるシステムとした .

\section{2. 医師の投与設計時の調整}

医師は電子カルテに登録されたレジメンに基づいて抗 がん斉を処方設計した．電子カルテには，標準的な投与 量や投与スケジュールが登録されている．しかし，患者 の肝機能，腎機能の低下，副作用が発現したために減量 が必要となった場合など，患者の状態にあわせ医師がレ ジメンの投与量，投与スケジュールを調整し処方設計す る必要が生じる．このようなケースに対応するため，当 
院では投与量，投与時間，投与速度，投与開始時間，点 滴ルート, 抗がん斉を希釈する輸液の種類の変更, 薬剂 の削除，抗がん斉以外の薬剂の追加が可能なシステムと した。

3. 薬斉師の処方鑑査体制，調製前処方鑑査薬剂師によ る処方鑑査方法

当院薬剂部ではリスク軽減のため，抗がん剂を含む注 射処方せんの鑑査を行う調製前処方鑑査薬剂師を配置し た . 処方せんが出力された後, 病棟に調製済みの薬剂を 払い出すまでに調剂を行う薬阂師，調製前処方鑑査薬㓢 師，調製を行う薬斉師，調製後鑑査薬剂師の 4 名の薬斉 師で処方内容の確認を行うこととした .

調製前処方鑑査薬斉師は翌日使用開始の抗がん斉を含 む処方内容について, 平日(月曜日から金曜日)の 15 時 から 17 時の間に処方鑑査を行った。調製前処方鑑査薬 斉師による処方鑑査の手順を示した(図 2). 調製前処方 鑑査薬斉師は, 電子カルテの医師の記載欄で医師の治療 方針を確認した後 , レジメン内容と処方内容が同じであ るかどうか確認した .レジメン内容は電子カルテ画面で 確認することができる．弚の際，医師記録欄の用量調節 に関する内容と用量設定が一致していること，過去の抗 がん斉投与歴, 薬斉師による問い合わせ記録もあわせて 確認した . 前回処方内容と選択されたレジメンが異なる 場合は，医師のカルテ記載画面に关の旨か記載されてい るかどうかを確認した . 記載されていない場合は医師に 確認した ·薬剤師は疑義照会した内容を電子カルテに記 録した。

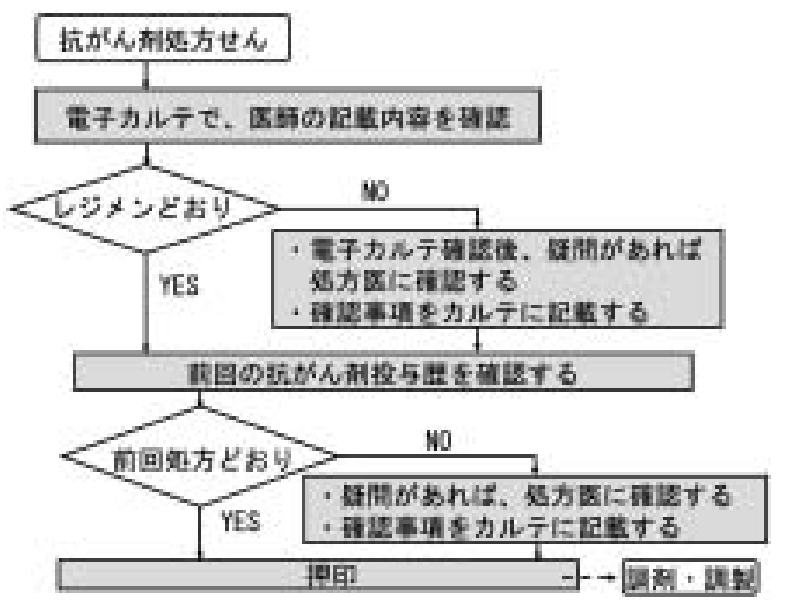

图 2 . 処方鑑査手順

電子カルテに登録されているレジメンと処方せんを照らし 合わせて，レジメンと処方が一致しているかどうかを確認 する . 前回処方やカルテ記載画面の医師の治療方針を確認 し，疑義がある場合は医師に問い合わせる .
結果

対象患者の平均年齢は $65 \pm 11$ 歳であった. 診療科の 内訳は外科 91 名 $(24.1 \%)$ ，血液内科 84 名(22.3\%)，呼吸 器科 53 名 $(14.1 \%)$, 泌尿器科 51 名(13.5\%), 消化器内科 34 名 $(9.0 \%)$ ，産婦人科 27 名 $(7.2 \%)$ ，放射線科 27 名 $(7.2$ $\%)$, 耳鼻科 4 名 $(1.1 \%) ，$ 脳神経外科 4 名 $(1.1 \%) ，$ 皮膚 科 1 名 $(0.3 \%)$, 眼科 1 名 $(0.3 \%)$ であった。

調製前処方鑑査薬斉師が調査期間中に鑑査した抗がん 剂処方せん枚数は 1,275枚, 1 力月平均処方せん枚数は 213 枚であった . 調製前処方鑑査薬剂師は1日に 1 2 名の薬剂師が鑑査を行った .調査期間 6 力月間(121日間) において，処方鑑査に要した時間の合計は 83 時間 35 分，1枚あたりの平均処方鑑査時間は 3.5 分であった . 調査期間中の疑義照会件数の合計は 105 件(8.2\%)であっ た、疑義照会した内容を「(1)カルテに処方鑑査に必要な 情報か記載されていなかったため確認した .」,「(2医師 カルテ記載内容と実際に処方された内容が異なっていた ため確認した .」,「(3)薬学的視点から処方内容が不適切 である可能性が考えられたため確認した 」」「(4)カルテ に入力されているパラメータが誤っていた 」」「「(5)前回 処方の確認により処方内容が不適切である可能性が考え られたため確認した .」の5 項目に分類し，「疑義照会件 数」,「疑義照会後に変更になった件数」についてまとめ た(表 1).

薬斉師か疑義照会したことにより，処方が変更され， 適正化された件数は疑義照会 105 件中 11 件(10.5\%)で あった．疑義照会したことにより処方か湾更され，適正 化された内容の内訳を示した(表 2) . 用量に関する内容 が 6 件(54.5\%)，薬斉の処方漏れが 3件(27.3\%)，内服薬 と注射薬での重複処方が1件(9.1\%)，不要な抗がん斉処 方が中止されていなかったものが1件(9.1\%)であった . 用量の不備のなかには, 体重が適切に入力されていな かったことに起因する内容が 3 件含まれていた .

さらに, 薬斉師は医師が治療方針をカルテに記載して いない，また，用量を調整しているにもかかわらず理由 を記載していないなどの理由から，処方変更には至らな かった処方について疑義照会を行っていた．

\section{1. レジメン管理と疑義照会内容}

本研究で疑義照会した処方のなかには，レジメン登録 項目である点滴時間と速度，抗がん剂を溶解する輸液の 薬剂名や投与量，投与間隔が不適切な処方，制吐剤，ア レルギーを予防する薬㓢の処方漏れなど，修正を必要と する処方はみられなかった .

2. 医師による投与設計時の調整と疑義照会内容 医師が処方設計時にレジメンを調整する必要が生じた 
表 1 . 疑義照会内容(全 105件)

疑義照会した内容を 5 項目に分類し, 疑義照会件数, 疑義照会後に変更になった

件数とともに示した .

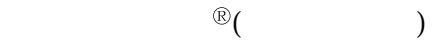

ティーエスワン ${ }^{\circledR}($ テガフール・ギメラシル・オテラシルカリウム配合剂)

\begin{tabular}{|c|c|c|}
\hline 疑義照会内容 & 件数 & $\begin{array}{l}\text { 疑義照会後 } \\
\text { 変史件数 }(\%)\end{array}$ \\
\hline \multicolumn{3}{|c|}{ (1)カルテに処方鑑榃に必要な情報が記載されていなかったため確認した。 } \\
\hline ・レジメンの種類が記載されていなからた。 & 40 & $0(0 \%)$ \\
\hline ・用量が記載されていなかった。 & 24 & $0(0 \%)$ \\
\hline 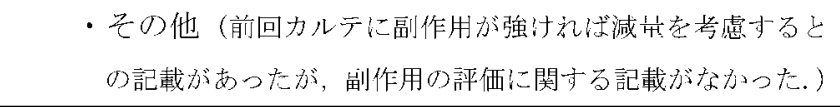 & 1 & $0(0 \%)$ \\
\hline \multicolumn{3}{|c|}{ (2)医師力ルテ記載内容と実際に処方された内容が具なっていたため確認した. } \\
\hline ・レジメンの種類が異なっていた。 & 5 & $1(20 \%)$ \\
\hline $\begin{array}{l}\text { ・レジメンから一部の抗がん剂を削除しているが，削 } \\
\text { 除する旨とその理由についての記載がない. }\end{array}$ & 1 & $0(0 \%)$ \\
\hline $\begin{array}{l}\text { ・カルテに記載されている抗がん戍のうち処方されて } \\
\text { いないものがあった. }\end{array}$ & 2 & $2(100 \%)$ \\
\hline $\begin{array}{l}\text { ・内服抗がん凬(ラ゙ィーエスワン®)の投与スケジュー } \\
\text { ルと処方量があっていなかった. }\end{array}$ & 1 & $0(0 \%)$ \\
\hline ・カルテに中止と書かれていたが処才されていた。 & 2 & $1(50 \%)$ \\
\hline ・用量が異なっていた。 & 8 & $1(13 \%)$ \\
\hline ・捜与Hが異なっていた。 & 2 & $0(0 \%)$ \\
\hline \multicolumn{3}{|c|}{ (3)薬学的視点から処力内容が不適切である可能性が考えられたため確誌した. } \\
\hline 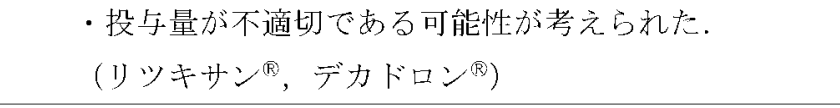 & 3 & $1(33 \%)$ \\
\hline $\begin{array}{l}\text { ・レジメン登録された注射薬抗がん剂の他に内服薬の } \\
\text { 抗がん剂が処方されていた. }\end{array}$ & 2 & $1(50 \%)$ \\
\hline ・リツキサン者希釈する輸液の量が不適切で市った。 & 1 & $1(100 \%)$ \\
\hline 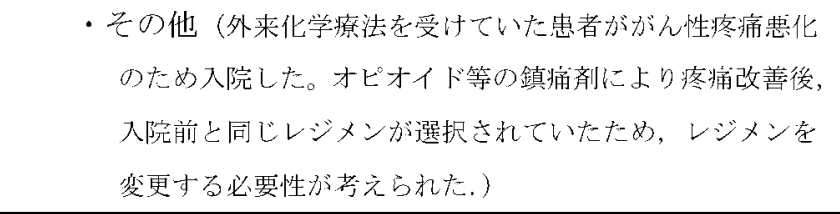 & 1 & $0(0 \%)$ \\
\hline (4)カルテに人力されているパラメータが誤っていた. & 6 & $3(50 \%)$ \\
\hline \multicolumn{3}{|l|}{ (5)前回処力の確誌により処力内容が不適切である可能性が } \\
\hline $\begin{array}{l}\text { 考えられたため確認した。(医師のカルデに用量変更の記 } \\
\text { 载がなかったが, 変更されていた。) }\end{array}$ & 6 & $0(0 \%)$ \\
\hline
\end{tabular}

にもかかわらず，調整されていなかった処方が疑義照会 11 件中 3 件 $(27.3 \%)$ みられた . 光の疑義照会内容は，「リ ツキサン・(リツキシマブ)の用量が $582 \mathrm{mg}$ と処方設計画 面で自動計算されたままになっており，600 mgに調整 されていなかった .」,「リツキサン ${ }^{\circledR}$ 溶解する生理食 塩液の量が , 溶解後にリツキサンが $10 \%$ になるように 調整されていなかった .」,「デカドロン®(デキサメタゾ
ン)をレジメンで登録している量よりも増量して処方さ れるはずであったが , 増量されていなかった .」などで あり，すべて用量に関する内容であった .

3. 薬斉師の処方鑑査体制と調製前処方鑑査薬剂師によ る処方鑑査方法

調製前処方鑑査薬剂師は, 調斉, 調製など処方鑑査以 
表 2 . 薬斉師の疑義照会により変更となった処方の詳細

薬斉師の疑義照会によって变更となった処方について, 变更前と变更後を示した．

\begin{tabular}{|c|c|}
\hline 変更解 & 変更後 \\
\hline \multicolumn{2}{|l|}{ <用量に関与る委の水6 件 $(54.5 \%)>$} \\
\hline $\begin{array}{l}\text { ・リツキサン®が } 582 \mathrm{mg} \text { 処方されていた. } \\
\cdots 1 \text { 件 }(9.1 \%)\end{array}$ & 600mg に変更された. \\
\hline $\begin{array}{l}\text { ・リツキサン办 } 400 \mathrm{mg} \text { 処方されていたが, } \\
\text { 希釈する牛理食盐湾の用呈が } 450 \mathrm{~mL} \text { とな } \\
\text { っていた. } \cdots 1 \text { 件 }(9.1 \%)\end{array}$ & 生理食塩液の用量が $360 \mathrm{~mL}$ に変更された。 \\
\hline $\begin{array}{l}\text { ・カルデにデカドロン用量が } 12 \mathrm{mg} \text { と記載 } \\
\text { されていたが，8mg 処方されていた. } \\
\quad \cdots 1 \text { 件 }(9.1 \%)\end{array}$ & デカドロンハのの用量が $12 \mathrm{mg}$ に変更された. \\
\hline $\begin{array}{l}\text { • 用量計算の元になるパラメータである体重 } \\
\text { が䛊入力されていたため, 䛊った用量が処 } \\
\text { 万されていた. } \cdots 3 \text { 件 }(27.3 \%)\end{array}$ & 体重が訂正され，用量が訂正された。 \\
\hline \multicolumn{2}{|l|}{$<$ 薬剂处与漏れ $\cdots 3$ 俳 $(27.3 \%)>$} \\
\hline $\begin{array}{l}\text { ・カルテに「R-CHOP」と記載されていたがリ } \\
\text { ツキサン多が処方されていない. } \\
\text { ‥1件 }(9.1 \%)\end{array}$ & リツキサン为が処方された。 \\
\hline $\begin{array}{l}\text { ・カルラ゙にオンコビン投与と記载されてい } \\
\text { たが処方されていなかった. …2件 (18.2) }\end{array}$ & オンコビン®が処方された。 \\
\hline \multicolumn{2}{|l|}{ <重複 $\cdots 1$ 件 $(9.1 \%)>$} \\
\hline $\begin{aligned} \text { ・化学䝤法とニーエフラ゙ィ } \mathrm{E}^{\mathbb{E}} \text { 顆粒の投薬が } \\
\text { 同じ日に指示されていた。 } \cdots 1 \text { 件 }(9.1 \%)\end{aligned}$ & $\begin{array}{l}\text { ユーエフラ゙ィ } \mathrm{E}^{\mathbb{R}} \text { 顆粒の投与が巾トされ } \\
\text { た. }\end{array}$ \\
\hline \multicolumn{2}{|l|}{ くその他 $\cdots 1$ 件 $(9.1 \%)>$} \\
\hline $\begin{array}{l}\text { ・カルテに入院延期と䛉載されていたが，抗 } \\
\text { がん剤处すが取り消されていなかった. } \\
\text { ‥1件 }(9.1 \%)\end{array}$ & 抗がん剂処方が取り消された。 \\
\hline
\end{tabular}

外の業務は行わず，処方鑑査に集中できる環境とした．

処方鑑査ではレジメンどおりであるか否かの確認 , 前 回処方どおりであるか否かの確認を行った .レジメンど おりの処方であるか否かを確認することにより，体重の 誤入力に起因する用量が不適切な処方，必要な抗がん剂 の処方漏れについて疑義照会することができ，処方が適 正化できた . 前回処方どおりであるか否かの確認は , 医 師が処方設計時に用量の減量や副作用を予防するための 薬剂の追加，増量など，レジメンの調整が必要であるに もかかわらず，調整せずに処方する可能性が考えられる ため，レジメンどおりであるか否かの確認に加え行って いる.しかし，本研究においては前回処方の確認によっ て見出された不適正な処方はみられなかった .

\section{考察}

がん薬物療法における疑義照会率は約 $5 \%$ との報告が
ある4 . また，約 30\% とした報告では，疑義照会率が高 い理由としてプロトコルと一致しない処方についてすべ て疑義照会を行っていることを理由として挙げてい $ろ^{5)}$. 処方変更率については, 抗悪性腫瘍薬が他の注射 薬に比べて処方変更率が $4.5 \%$ と高いとの報告がある6). 当院薬剂部における 6 力月間の疑義照会率は処方せん 1,275枚中 105 件(8.2\%)で，処方変更率は 11 件(10.5\%) であった．当院薬剤部では，処方鑑査手順に従って，電 子カルテの医師の記載欄に理由の記載がないにもかかわ らず，レジメン登録内容と処方内容が一致しない場合に 疑義照会を行っている．弚のため，レジメンどおりでな い処方についてすべて疑義照会を行っている施設に比べ て，低い疑義照会率になっていると考えられた．

薬剂師の疑義照会により変更, 適正化された処方は, (1)医師の治療方針と処方内容を確認することで適正化さ れた処方，(2)レジメンどおりであるか否か確認すること で適正化された処方，(3)薬剂師の薬剂に関する知識に 
よって適正化された処方，(4)薬剤師のオーダリングシス テムの利点, 欠点に関する知識によって適正化された処 方に分類できると考える

(1)医師の治療方針と処方内容を確認することにより適 正化された処方は, “電子カルテの医師記載欄には RCHOP と記載されていたが実際の処方ではリツキサン ${ }^{\circledR}$ が処方されていなかった”，“電子カルテの医師記載欄に オンコビン ${ }^{\circledR}$ (ビンクリスチン)投与と記載されていたが 処方されていなかった”"“電子カルテの医師記載闌にデ カドロン ${ }^{\circledR} 12 \mathrm{mg}$ と記載されていたが，8 $\mathrm{mg}$ が処方され ていた”“"カルテに入院延期と記載されていたが, 中止 されていない抗がん斉処方がみられた”事例であった . 医師が意图した内容と一致しない処方か設計されたこと から，治療方針を確認することは必須であることが明ら かとなった .

(2)レジメンどおりであるか否か確認することで適正化 された処方では, 用量がレジメンと一致しなかったため 処方せんを確認したところ，体重が正しく入力されてい なかった処方が3件みられた．体重は体表面積自動計算 のパラメータの一つであり，体重や自動計算された体表 面積の値をもとに用量が自動計算される．これら 3 件に ついてはレジメンどおりであるか確認することによって 薬斉師が疑義照会を行い, 看護師が体重を修正し処方が 適正化できた .このようなことから，処方内容とレジメ ンを照合することが，処方の適正化に有用であることが 明らかとなった .

(3)薬㓢師の薬㓢に関する知識によって適正化された処 方では,リツキサン ${ }^{\circledR}$ の用法が不適切な処方がみられ た。リツキサンは調製後の濃度が $10 \%$ になるように
調製しなければならない》．しかし，電子カルテでは身 長と体重から自動計算された体表面積をもとに $375 \mathrm{mg} /$ $\mathrm{m}^{2}$ となるように用量が自動計算される．弚のため， 10 \%に調製しやすい用量にするには，医師が用量を修正し なければならない，さらに，希釈する輸液の量も自動計 算されないため，医師が処方設計時に計算し用量を入力 している . 本研究結果では, 医師がリツキサン ${ }^{\circledR} 600 \mathrm{mg}$ 投与することを意図していたにもかかわらず，リツキサ ン $の$ 用量を $582 \mathrm{mg}$ のまま修正していなかった処方， リツキサン®を希釈する生理食塩液の用量が不適切で あつたため，調製後濃度が 10\% とならない処方がみら れた . これらの処方は医師が用量を修正する段階におい て発生した不適切な処方であったが, リツキサン ${ }^{\circledR} の$ 使 用方法を理解していた薬斉師が鑑査し医師に疑義照会し たことで，適正化することができた .

(4)オーダリングシステムの特性に関する知識によって 適正化された処方としては，化学療法と同じ日にユーエ フティ $\mathrm{E}^{\circledR}($ テガフール・ウラシル)顆粒がオーダされて いた処方がみられた．当院の電子カルテシステムは内 · 外用薬と注射薬の処方オーダ画面，投与歴画面は独立し ており，内用薬と注射薬て抗がん剂が処方された場合， 電子カルテに警告を表示することができない．オーダリ ングシステムの特性を理解していた薬剤師が，注射薬だ けでなく，内・外用薬の投薬歴も確認したことにより，

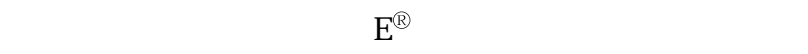
の重複を防ぐことができた .

以上のことから，医師の治療方針の確認と，レジメン とオーダされた処方内容の照合, 薬阂, オーダリングシ ステムに関する知識が処方の適正化に有用であることが

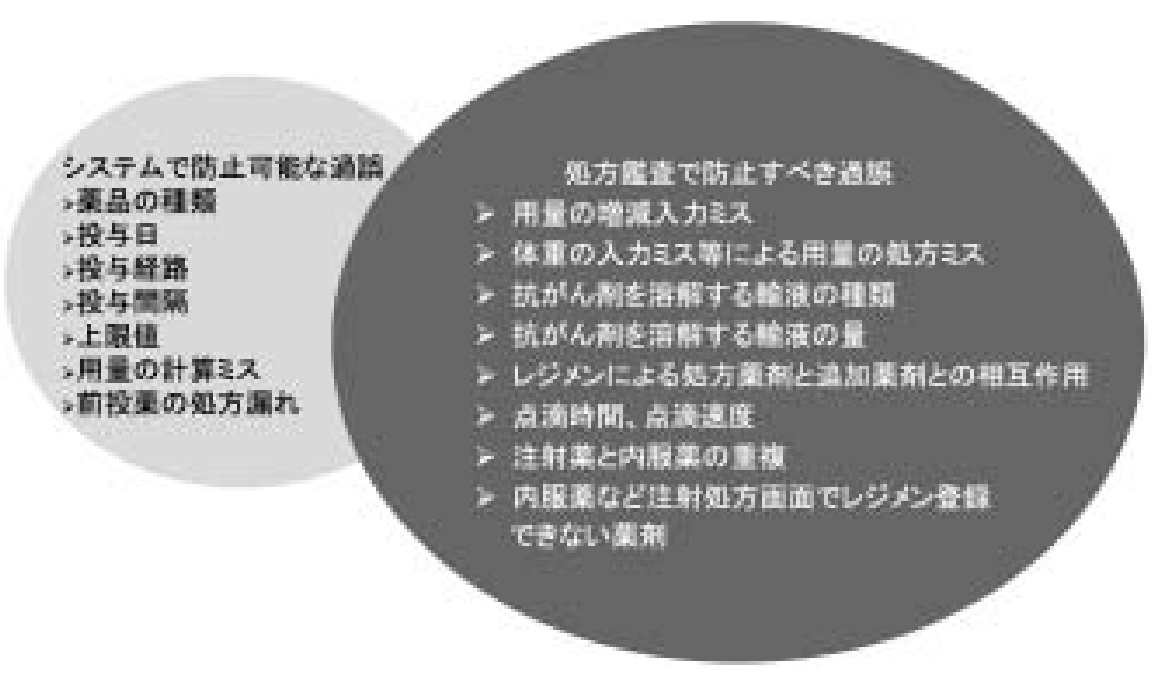

图 3 . システムで防止可能な過誤と処方鑑査で防止すべき過誤

システムですべての過誤を防止することはできない，薬㶡 師はシステムで防止可能な過誤と，処方鑑査で防止すべき 過誤を認識して処方鑑査を行うべきである。 
明らかとなった . システムで防止可能な過誤と薬斉師に よる処方鑑査で防止すべき過誤について示した(図 3) . また, 本研究の調査対象においてはみられなかったが, 投与時間，投与開始時間，抗がん斉を希釈する輸液の種 類と用量，追加された抗がん斉以外の処方とレジメン処 方との相互作用など， システムの特性上過誤が生じる可 能性もある.薬斉師はこのような不適正な処方を確認し ながら，処方鑑査を行う必要がある。

システム改善には時間と費用を要す．また，どんなに システムを改良しても防ぎきれない過誤やリスクが生じ る.薬阂師はシステムで防止可能な過誤と，処方鑑査で 防止すべき過誤を認識して処方鑑査を行うべきである． 前述した調製前処方鑑査薬剂師か防いだ過誤は，レジメ ンが十分に管理されたうえで生じたものである．がん薬 物療法では複雑なプロトコルが施行されるため, 専門薬 剂師の必要性が報告されている8. 適切にレジメン管理 が行われていても，医師が患者にあわせてレジメンを調 整して処方する場合，不適切な処方か設計されるリスク が生じる. 薬剂師は薬学的知識に加え, 電子カルテシス テムや処方せんが発行されてから患者に薬㓢が投与され るまでのながれについても把握し, 処方鑑査を行う必要 がある.十分な処方鑑査は有効かつ安全ながん薬物療法 に必須であり，重篤な有害事象の回避に役立つものであ る。

\section{引用文献}

1) 森川明信，がん化学療法レジメンによるがん薬物療 法の処方監査と薬歴管理, 月刊薬事 , 46, 2313-2320 (2004).

2)“薬阂部，抗がん斉業務ハンドブック”、国立がんセ ンター薬斉部編，じほう，東京，2006, pp.43-52.

3）直良浩司，岩本喜久生，抗がん斉の処方鑑査におけ るリスクマネジメント，薬局 , 55, 1499-1507 (2004).

4) 續木康夫, 梨あゆみ, 西田真佐夫, 中村慶, 竹村契 二, 和田洋忠, 長谷川健次, 南木勝子, 折原三枝子, 陰下敏昭, 森田吉多佳, 由宇芳才, 粉川俊則, 癌化 学療法の処方確認システムの構築，医療薬学，30, 121-128 (2004).

5) 濱宏仁, 平畠正樹, 田村昌三, 岩森繁夫, 片岡和三 郎，外来がん化学療法における処方疑義照会の解 析，医療薬学，32, 816-823 (2006).

6) 名德倫明, 五十嵐恵美子, 富田由美, 村山洋子, 中 西晶子, 下村一德, 深尾知子, 乾とし子, 藤原紀子， 阪本絵美，川口進一，土師久幸，「処方監査におけ る注意点一覧」を利用した注射薬処方監査の現状と 谷の評価，医療薬学，30, 594-600 (2004).

7) リツキサン ${ }^{\circledR}$ インタビューフォーム, 全薬工業株式 会社, 2007 年 5 月。

8）宇佐美英績，一川悦子, 中尾俊也, 岡田和智, 山崎 太，血液内科における薬阂管理指導(第 3報)〜化学 療法の複雑化による専門薬斉師の必要性〜，日本病 院薬斉師会杂隹誌，39, 833-837 (2003). 